\title{
VERTEBRATE PALEOECOLOGY OF THE LATE PLIOCENE ARROYO SALADA LOCAL FAUNA, BAJA CALIFORNIA SUR, MEXICO
}

\section{PALEOECOLOGIA DE VERTEBRADOS DE LA FAUNA LOCAL DEL ARROYO SALADA DEL PLEISTOCENO TARDIO, BAJA CALIFORNIA SUR, MEXICO}

\author{
James R. Ashby \\ Dept. of Earth and Space Sciences \\ UCLA \\ Los Angeles, Ca. 90024
}

Ashby, James R. Vertebrate Paleoecology of the Late Pliocene Arroyo Salada Local Fauna, Baja California Sur, México. Paleoecologia de vertebrados de la fauna local del Arroyo Salada del Plioceno tardío, Baja California Sur, México. Ciencias Marinas; 13(3): 23-30, 1987.

\begin{abstract}
Ambiguites have arisen regarding the age of the Salada Formation at its type locality in Arroyo Salada, Baja California Sur, México. Fossil vertebrates, although mentioned by previous workers have either been lost or destroyed by various misfortune. A new collection has been made and described herein, to record a small vertebrate fauna present in the type section. Surprisingly precise age and paleoenvironmental determinations can be made on this relatively small fauna consisting of ten sharks, one bony fish, and one ray. It is now apparent that the Salada Formation, in its type section is late Pliocene in age and represents a slightly offshore marine environment adjacent to a brackish water environment, like Magdalena Bay today.
\end{abstract}

\section{RESUMEN}

Ambigüedades han surgido acerca de la edad de la Formación Salada en su localidad tipo en Arroyo Salada, Baja California Sur, México. Fósiles vertebrados, aunque mencionados por cient $\{-$ ficos anteriores se perdieron o fueron destruidos debido a una serie de circunstancias adversas. Una nueva colecta se hizo y se describe este trabajo a fin de registrar una pequeña fauna de vertebrados presentes en la sección tipo. Sorprendentemente,la edad precisa y las determinaciones paloeambientales se pueden determinar en esta fauna relativamente pequeña que consiste de diez tiburones, un pez huesudo y una raya. Está claro ahora que la Formación Salada, en su sección tipo, pertenece al Plioceno tardfo y representa un ambiente marino ligeramente mar adentro adyacente a un ambiente de agua solubre, como en la Bahía Magdalena hoy.

\section{INTRODUCTION}

Marine rocks of the Pliocene Salada Formation occur in many places throughout the southern portion of Baja California, particularly along edges of the Magdalena Plain on the Pacific coast of the Peninsula. Heim (1922) named the Salada Formation for marine sediments which form a "...low and unfolded plateau, which extends from $\mathrm{La}$ Salada Ranch as far as Arroyo Colorado, Lat.

\section{INTRODUCCION}

Las rocas marinas del Plioceno de la Formación Salada se presentan en muchos sitios a lo largo de la porción sur de Baja California, particularmente a lo largo de los márgenes de la Planicie Magdalena en la costa del Pacifico de la Península. Heim (1922) nombró Formación Salada a sedimentos marinos que forman "una planicie baja y no plegada, que se extiende desde el Rancho La 
$24^{\circ} 15^{\prime} \mathrm{N}$ a distance of $45 \mathrm{~km}$, where it extends still farther southeast for an unknown distance". The type section was described by Heim (1922) to be a sequence of marine sediments exposed in Arroyo Salada, 1400 meters northeast of the La Salada ranch house (Figure 1). When the type locality was visited in March of 1984, the ranch house was seen to be long desorted and badly weathered, but still recognizeable. The stratigraphic column in Figure 2 is reproduced from Heim's original paper (1922, p.544, Fig. 5). Vertebrate fossils were collected from unit 2 in Figure 2. This study represents the first description of vertebrate fossils from the type section of the Salada Formation. These fossils are here deemed the Arroyo Salada Local Fauna.
Salada hasta el Arroyo Colorado, Lat $24^{\circ} 15^{\prime} \mathrm{N}$, una distancia de $45 \mathrm{~km}$, en donde se extiende hacia el sureste hasta una distancia desconocida". La sección tipo fue descrita por Heim (1922) como una secuencia de sedimentos marinos expuestos en el Arroyo Salada, 1400 metros al noroeste de la casa del Rancho La Salada (Figura 1). Cuando la localidad tipo fue visitada en marzo de 1984, la casa del rancho aparentaba estar desocupada y descuidada, pero continuaba reconocible. La columna estratigrafica de la Figura 2 es reproducida del trabajo original de Heim (1922, p.544, Fig. 5). Se colectaron fósiles de vertebrados de la unidad 2 en la Figura 2. Este estudio es la primera descripción de fósiles de vertebrados de la sección tipo de la formación Salada.

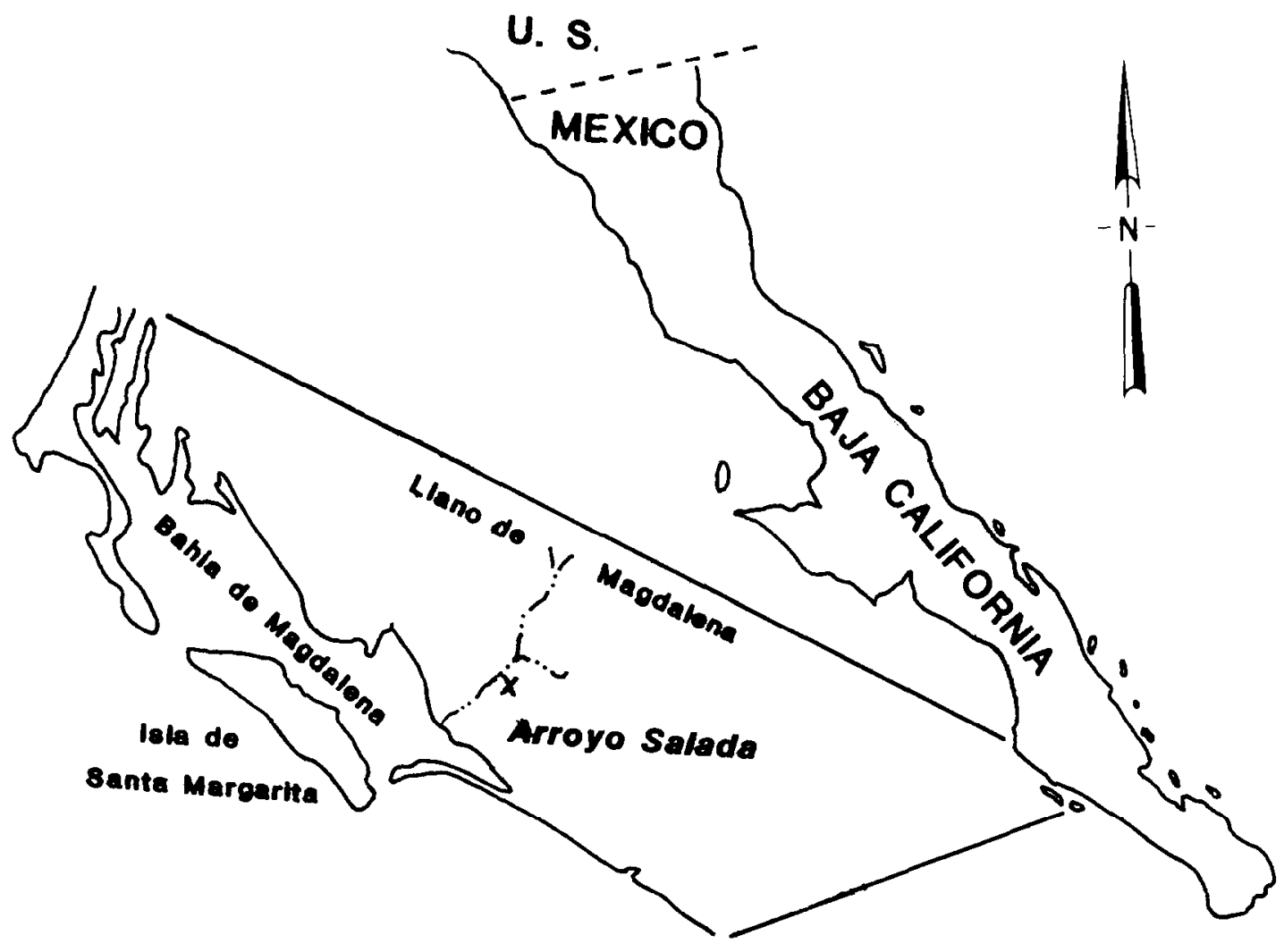

Figure 1. Localization of the study area.

Figura 1. Localización del área de estudio. 


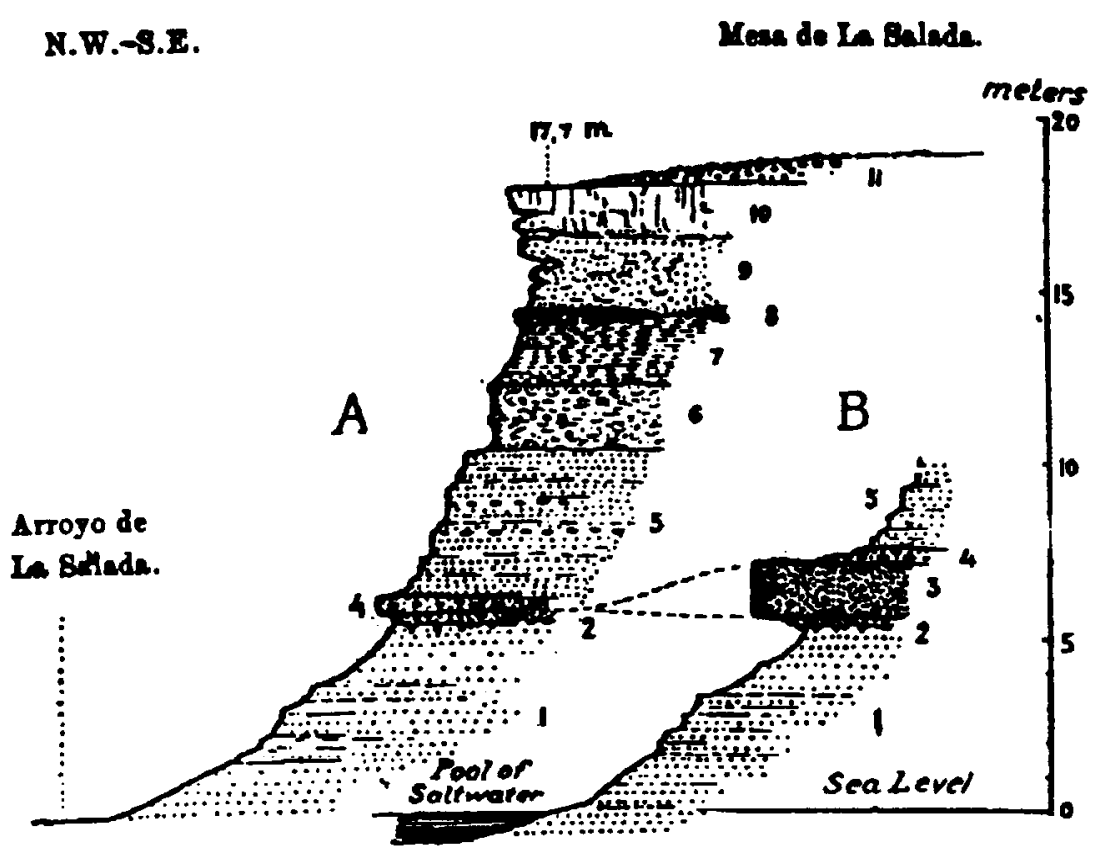

Figure 2. Modified from Heim (1922, p. 544, Fig. 5). The type Salada Formation of Rancho La Salada. A. Section $1400 \mathrm{~m}$ NE of abandoned ranch house. B. Section $1000 \mathrm{~m} \mathrm{NE}$ of abandoned ranch house. 1. Greenish, poorly indurated sandstone, salty, apparently without fossils; abrupt contact toward $2.0 .3 \mathrm{~m}$ gravelly sand, containing basalt pebbles and many poorly preserved mollusks; Balanus, Turitella, Chione, Chrysodomus, Calliostoma, Oliva, Conus, Tellina, Bryozoa and shark teeth, (Bed examined in this study). 3.1 to $2 \mathrm{~m}$ bank of well indurated sandstone with gastropods and bivalves. $4.0 .5 \mathrm{~m}$ greenish gravelly-sand gradational with $5.4 .1 \mathrm{~m}$ of poorly indurated sandstone, gray to violet on weathed surface, greenish to bluish on fresh surfaces, containing pebbles of green shale. $6.1 .9 \mathrm{~m}$ yellow gravelly sand with abundant mollusks, also Balanus, and bryozoans. $7.1 .8 \mathrm{~m}$ fine grained green sandstone without shells. 8.0 to $0.25 \mathrm{~m}$ of cobbly to pebbly basaltic conglomerate that is encrusted with lime. $9.2 .0 \mathrm{~m}$ grey concretionary sandstone with abundant mollusk fragments including Pecten; gradational with $10.1 .5 \mathrm{~m}$ chalky, brecciated limestone without shells. 11. Pleistocene Mesa conglomerate, consisting chiefly of basaltic clasts.

Figura 2. Modificadopor Heim(1922, p. 544, Fig. 5). La localidad tipo de la Formación Salada del Rancho La Salada. Sección A. $1400 \mathrm{~m}$ NE de la casa de rancho abandonada. Sección B. $1000 \mathrm{~m}$ NE de la casa de rancho abandonada. 1. Arenisca pobremente endurecida, halina, aparentemente sin fósiles, de color verdoso; contacto abrupto hacia $2.0 .3 \mathrm{~m}$ de arena gravosa, con contenido de clastos basálticos y bastantes moluscos pobremente preservados; Balanus, Turitella, Chione, Chrysodomus, Calliostoma, Oliva, Conus, Tellina, Bryozoa y dientes de tiburón, (yacimiento examinado en este estudio). 3 . 1 a $2 \mathrm{~m}$ de arenisca de banco bien endurecida con gastrópodos y bivalvos. 4 . $0.5 \mathrm{~m}$ arena gravosa verdosa gradada con 5.4 . $1 \mathrm{~m}$ de arenisca pobremente endurecida, superficie erosionada gris a violeta, superficie fresca verdosa a azulosa, conteniendo clastos de esquisto verde. $6.1 .9 \mathrm{~m}$ arena gravosa amarilla con abundantes moluscos así como Balanus, y briozoarios. $7.1 .8 \mathrm{~m}$ arenisca fina verde sin conchas. 8.0 a $0.25 \mathrm{~m}$ de conglomerado adoquinado a guijarroso, incrustado con calcita. $9.2 .0 \mathrm{~m}$ de arenisca gris solidificado con abundantes fragmentos de moluscos, Pecten incluso; gradada con $10.1 .5 \mathrm{~m}$ de material calcáreo, brecha caliza, sin conchas. 11. Conglomeradode Mesa Pleistocena, consistente principalmente de clastos baślticos. 
The invertebrates present at this locality are not discussed in the present study. They are currently being examined by Judith Terry-Smith of the U.S. Geological Survey and their analyses will be published as a separate report. In general, the shell material at this locality is poorly preserved. However, the molds of some of the specimens are of excellent quality, allowing rather specific determination.

VERTEBRATES (Arroyo Salada Local Fauna)

A limited assemblage of sharks, rays, and bony fishes is here described (Table I) from orangish-brown sandstones within the type section of the Salada Formation, Arroyo Salada, Baja California Sur, México. Ten sharks, one ray, and one bony fish comprise the vertebrate fauna collected at this locality. This collection is the only one to date that still remains availáble for study. Although Heim (1922, p.35) mentions the presence of well-preserved shark teeth in the Salada Formation type section, he does not describe them, nor do they seem to have been described elsewhere. These collections seem to have been misplaced or destroyed as a result of the second world war (Judith Terry-Smith, personal communication). The fossils obtained from the present investigation are designated with USGS locality numbers, and have been deposited in the vertebrate paleontology collections at the Menlo Park, California branch of the US Geological Survey.

Table II summarizes the known local stratigraphic ranges of the various shark taxa collected at Arroyo Salada. These concurrent range data support an early late to late Pliocene age assignment for the Arroyo Salada local fauna.

The shark fauna is comparable (Table III) to that obtained from the upper Pliocene Salada Formation at Rancho Algodones, $120 \mathrm{~km}$ southeast of La Paz (Espinosa, 1979); and with a diverse shark fauna from the upper Pliocene Tirabuzon Formation at Corkscrew Hill; just north of Santa Rosal a (Applegate and Espinosa, 1981; Wilson, 1985). They all appear to be of approximately the same age.
Estos fósiles son nombrados en este trabajo como Fauna Local de Arroyo Salada.

Los invertebrados presentes en esta localidad no se discuten en el presente estudio, actualmente estón siendo examinados por Judith Terry-Smith, del US GeologicalSurvey y su anślisis serb publicado como un reporte aparte. En general, el material de conchas en esta localidad está pobremente preservado. Sin embargo, los moldes de algunos especimenes son de excelente calidad, y permiten su determinación a especie.

\section{VERTEBRADOS (Fauna Local Arroyo Sala-} da)

Un ensamblaje limitado de tiburones, rayas y peces óseos se describen aquí (Tabla I) procedentes de las areniscas naranja-café de la sección tipo de la Formación Salada, Arroyo Salada, Baja California Sur, México. Diez tiburones, una raya y un pez óseo comprenden la fauna de vertebrados recolectada en esta localidad. Esta colección es la única que pueda ser utilizada para estudio. Pese a que Heim (1922, p.35) menciona la presencia de dientes de tiburón bién preservados en la sección tipo de la Formación Salada, no los describe, ni menciona que sean descritos en otro lugar. Esta colección aparentemente fue perdida o destruida como resultado de la Segunda Guerra Mundial (Judith Terry-Smith, com. pers.). Los fósiles obtenidos durante la presente investigación son designados por números de localidades de USGS y han sido depositados en la colecciones paleontológicas de vertebrados en Menlo Park, California del US Geological Survey.

La Tabla II resumc las variaciones estratigraficas locales conocidas de los varios taxa de tiburones colectados en Arroyo Salada. Estos datos permiten apoyar la idea de una edad Temprana tardia a tardía en el Plioceno para la fauna local del Arroyo Salada.

La fauna de tiburones es comparable (Tabla III) con la obtenida del Plioceno Superior de la Formación Salada en el Rancho Algodones, $120 \mathrm{Km}$ al sureste de La Paz (Espinosa, 1979); y con diversa fauna de tiburones del Plioceno Superior de la Forma- 
Table 1. Vertebrate taxa of the Arroyo Salada local Fauna; Type section of the Salada Formation, Arroyo Salada, Baja California Sur, Mexico.

Tabla 1. Taxa de vertebrados de la fauna local del Arroyo Salada; Sección tipo de la Formación Salada, Arroyo Salada, Baja California Sur, México.

$\begin{array}{ll}\text { Eugomphodus acutissima } & \text { Sharks } \\ \text { Isurus axyrinchus Rafinesque 1810 } & \text { Ragged-tooth shark } \\ \text { Rhizoprionodon longurio Jordan and Gilbert 1882 } & \text { Mako shark } \\ \text { Negaprion fronto Jordan and Gilbert 1882 } & \text { Sharpnose shark } \\ \text { Carcharhinus leucas Mueller and Henle 1841 } & \text { Lemon shark } \\ \text { Carcharhinus sp? \#1 } & \text { Bay shark } \\ \text { Carcharhinus sp? \#2 } & \text { Bay shark } \\ \text { Hemipristis serra Agassiz 1843 } & \text { Bay shark } \\ \text { Sphyma lewini Griffith and Smith, 1834 } & \text { Indian Ocean shark } \\ \text { Sphyma zygaena Linnaeus, } 1758 & \text { Hammerhead shark } \\ & \text { Hammerhead shark }\end{array}$

Myliobatoidea cf. Myliobatis sp?

Rays

Bony Fishes

Eithynnus sp?

Bat rays

Skipjack

Table II. Stratigraphic distribution of diagnostic fossil sharks of the Arroyo Salada local fauna. Modified from Espinosa (1979), some stratigraphic information from Applegate and Espinosa (1981), Applegate et al. (1979), Wilson, 1985, and Luis Espinosa (personal communication, Oct. 1985).

Tabla II. Distribución estratigráfica de fósiles de tiburones diagnóstico de la fáuna local del Arroyo Salada. Modificada por Espinosa (1979), alguna información estratigráfica de Applegate y Espinosa (1981), Applegate et al. (1979), Wilson, 1985, y Luis Espinosa (com. pers., Oct. 1985).

MIOCENE PLIOCENE PLEISTOCENE RECENT

Eugomphodus acutissima

Isurus axyrinchus

Rhizoprionodon longurio

Negaprion fronto

Carcharhinus leucas

Hemiprisitis serma

Sphyma lewini

Sphyma zygaena

\author{
$\mathrm{XXX} \mathrm{X} \times \mathbf{X X X X X}$

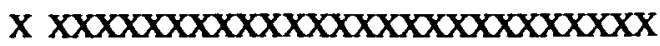 \\ XXXXXX XXXXXXXXXXXXXXXX

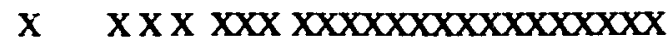

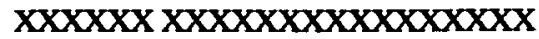

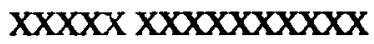 \\ $\mathrm{XX}$ XXXXX XXXXXXXXXXXXXXXX

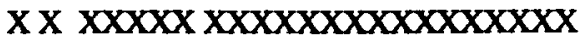


Table III. Comparison of the Arroyo Salada local fauna with taxa obtained at Rancho Algodones, Salada Formation (Espinosa, 1979); Corkscrew Hill, Tirabuzón Formation (Applegate and Espinosa, 1981) and with shark taxa currently living in mexican waters today (Applegate et al., 1979).

Tabla III. Comparación de la fáuna local del Arroyo Salada con taxa obtenida en Rancho Algodones, Formación Salada (Espinosa, 1979); Corkscrew Hill, Formación Tirabuzón (Applegate y Espinosa, 1981) y con taxa de tiburones que viven actualmente en aguas mexicanas (Applegate et al., 1979).

\begin{tabular}{|c|c|c|c|}
\hline $\begin{array}{l}\text { Arroyo Salada } \\
\text { Local Fauna }\end{array}$ & $\begin{array}{c}\text { Corkscrew Hill } \\
\text { Fauna }\end{array}$ & Rancho Algodones & $\begin{array}{c}\text { Modern Mexican } \\
\text { Shark }\end{array}$ \\
\hline Eugomphodus acutissima & $\mathrm{XXXX}$ & & \\
\hline Isurus axyrinchus & XXXX & XXXX & XXXX \\
\hline Rhizoprionodon longurio & $\mathbf{X X X X}$ & $\mathbf{X X X X}$ & $\mathbf{X X X X}$ \\
\hline Negaprion fronto & $\mathbf{X X X X}$ & $\mathbf{X X X X}$ & $\mathbf{X X X X}$ \\
\hline Carcharhinus leucas & $\mathbf{X X X X}$ & $\mathrm{XXXX}$ & $\mathbf{X X X X}$ \\
\hline Carcharhinus sp. \#1 & ???? & ???? & extinct form? \\
\hline Carcharhinus sp. \#2 & ???? & $? ? ? ?$ & extinct form? \\
\hline Hemipristis sema & $\mathbf{X X X X}$ & $\mathbf{X X X X}$ & \\
\hline Sphyma lewini & XXXX & $\mathrm{XXXX}$ & XXXX \\
\hline Sphyma zygaena & $\mathbf{X X X X}$ & XXXXX & $\mathbf{X X X X}$ \\
\hline
\end{tabular}

Paleoenvironmental inferences concerning the Arroyo Salada local fauna can be drawn from an examination of environmental and ecological requirements of modern shark analogs living today in Mexican waters (Applegate et al., 1979). The shark taxa of the Arroyo Salada local fauna are listed in Table III with their indicated presence or absence at the aforementioned localities and their presence today in mexican waters.

\section{DISCUSSION}

Even a small shark fauna such as the obtained from locality 85 -JS-17 can be used to interpret the paleonvironmental conditions that existed during the deposition of this section of the Salada Formation. The geologic age of these shark taxa, all obtained from the same bed, appear to be of early-late Pliocene age (see Table II).

The three species of Bay sharks (Carcharhinus) indicate a slightly brackish environment such as a lagoon, estuary or river. The lemon shark, Negaprion fronto is present- ción Tirabuzón en Corkscrew Hilll, justo al norte de Santa Rosalía (Applegate y Espinosa, 1981; Wilson, 1985). Todos ellos aparentemente son de la misma edad.

Pueden obtenerse inferencias Paleoambientes de la fauna local de Arroyo Salada del examen de los requerimientos ambientales y ecológicos de tiburones actuales análogos, que viven actualmente en aguas mexicanas (Applegate et al., 1979). Los taxa de los tiburones de la fauna local de Arroyo Salada se encuentran en la Tabla III y se indica la presencia o ausencia en las localidades mencionadas y la presencia actual en aguas mexicanas.

\section{DISCUSION}

Una pequeña fauna de tiburones como la obtenida de la localidad 85-US-17 puede ser usada para interpretar las condiciones paleoambientales que existieron durante la depositación de esta sección de la Formación Salada. La edad geológica de estos taxa de tiburones, todos obtenidos del mismo estrato, representan ser del Plioceno temprano-tardío (ver Tabla II). 
ly living in the Pacitic and Gulf of California from Bahia Magdalena to Guatemala. This species is only known to live in bays, in less than $\mathbf{2 0}$ meters of water. Hammerhead sharks currently can be found to live in a bit deeper water (pelagic) adjacent to the coast. The Ragged-tooth shark (Eugomphodus) is not found along the western shore of north America but a closely related genus, Odontapsis is currently found in Pacific waters and prefers slow moving water in shallow bays to a depth of $20 \mathrm{~m}$ (Jeff Seigel, personal communication, Oct. 1985). The mako shark Isurus axyrinchus is the only shark characteristic of an offshore to open-ocean environment. This species of mako is commonly associated with large teleost fish such as sailfish or marlin (Applegate et al., 1979).

The bat rays (Myliobatis) indicate water depths of less than 30 meters. The skipjack (Euthynnus) is commonly found in coastal waters immediately adjacent to the open ocean. The presence of the skipjack and the mako shark would tend to rule out an estuarine environment of deposition and seem to indicate that the fossil material was transported offshore, perhaps into a shallow embayment that was largely influenced by esturarine detritus.

Water temperatures were undoubtedly warm and sub-tropical as indicated by the presence of rays and the sharks Negaprion and Rhizoprionodon. However, these conclusions must be compared to those obtained from the examination of the invertebrate faunas.

\section{CONCLUSIONS}

The fauna collected from Arroyo Salada seems to indicate an offshore marine environment perhaps adjacent to a brackish water environment, like Magdalena Bay today. These waters were warm and sub-tropical similar to water temperatures that are present slightly south of this area today. The stratigraphic control of these sharks is quite good, indicating an early-late Pliocene to late Pliocene age for these sediments. These conclusions must be compred with those reached in the examination of the invertebrate taxa to make an accurate age and paleoenvironmental interpretation.
Tres especies de tiburones de Bahía (Carcharhinus) indican un ambiente tranquilo, como una laguna, estuario o río. El tiburón limón Negaprion fronto actualmente vive en el Pacífico y Golfo de California desde Bahía Magdalena hasta Guatemala. Esta especie se conoce que vive solo en Bahras, en menos de 20 metros de agua. Los tiburones martillo actualmente viven en aguas más profundas (pelégicas) adyacentes a la costa. El tiburón (Eugomphodus) no se encuentra a lo largo de las costas de Norte América pero un género muy cercanamente relacionado, Odontapsis es encontrado frecuentementeen aguas del Pacífico $y$ prefiere aguas tranquilas en bahías someras a una profundidad de $20 \mathrm{~m}$ (Jeff Seigel, comunicación personal, Oct. 1985). El tiburón mako Isurus axyrinchus es el único tiburón característico de aguas abiertas. Esta especie de mako comúnmente se asocia con los grandes teleostos como el pez espada o el marlin (Applegate et al., 1979).

Las rayas de Bah fa (Myliobatis) indican profundidades de menos de 30 metros. El Euthynnus es encontrado frecuentemente en aguas costeras inmediatamente adyacentes al mar abierto. La presencia de este último y del tiburón mako nos hace descartar un ambiente de depositación estuarino y parece indicar que el material fosil fue transportado hacia afuera, posiblemente a un ambiente somero que fue fuertemente influenciado por detritus estuarinos.

Las temperaturas del agua fueron indudablemente cálidas y sub-tropicales como indica la presencia de rayas y de los tiburones Negaprion y Rhizoprionodon. Sin embargo, estas coclusiones deberán ser comparadas a aquellas que se obtengan del examen de las faunas de invertebrados.

\section{CONCLUSIONES}

La fauna colectada en Arroyo Salada indica un ambiente marino de aguas abiertas posiblemente adyacente a un ambiente de rompiente, como Bahra Magdalena actualmente. Esas aguas fueron calidas y sub-tropicales, similares a las temperaturas de aguas inmediatas al sur de esa orrea actualmente. E1 control estratigrafico de estos tiburones es bueno e indican una edad del Plioceno temprano-tardio al Plioceno tardío para esos 


\section{ACKNOLEDGMENTS}

The author wishes to acknowledge Luis Espinosa-Arrubarrena of Long Beach State University who assisted with the identification of the sharks and provided many valuable references. Thanks also go to Jeff Seigel who also assisted me with identifications. Cam Swift identified the fish and Ed Wilson, Larry Barnes and Sam McLeod of the Los Angeles County Museum offered many helpful suggestions.

Many thanks also to Thomas A. Demére of the San DiegoNatural History Museum who reviewed the manuscript.

\section{LTERATURE CITED}

Applegate, S.P., Espinosa, L., Menchaca, L. and Sotelo, F. (1979) Tiburones Mexicanos: Subsecretaría de Educación e Investigación Tecnológica, Dirección General de Ciencia y Tecnología del Mar, México, 141 pp., 50 figs.

Applegate, S.P. and Espinosa, L. (1981) The Geology and Selachian Paleontology of Loma del Tirabuzón (Corkscrew Hill) Santa Rosalía, BCS, México. pp. 257-263 In (Ortleib, L. and Roldán, J. eds) Geology of northwestern Mexico and Arizona, Hermosillo (México), UNAM. Instituto de Geología, Estación del Noroeste.

Espinosa-Arrubarrena, Luis (1979) Los tiburones fósiles (Lamniformes) del Rancho Algodones, Baja California Sur, México. Published Thesis, UNAM. 56 pp. sedimentos. Estas conclusiones deberán ser comparadas, con las que se obtengan en el examen de los invertebrados para obtener una edad y un medio ambiente de depositación certeros.

\section{AGRADECIMIENTOS}

El autor desea agradecer a Luis Espinosa-Arrubarrena de Long Beach State University quién le auxilió con la identificación de los tiburones y proporcionó muchas referencias valiosas. Gracias también a Jeff Seigel quién también me asistió en la identificación. Cam Swift identifico el pez y Ed Wilson, Larry Barnes y Sam McLeod de Los Angeles County Museum ofrecieron muchas sugerencias valiosas. Muchas gracias también a Thomas A. Deméré de San Diego Natural History Museum quien revisó el manuscrito. pañol.

Sergio Pou realizo la traducción al Es-

Heim, A. (1922) Notes on the Tertiary of Southern Lower California (México). The Geological Magazine: Vol. 59, No. 12., p. 529-547.

Wilson, E. (1985) The spiral trace fossil Gyrolithes de Saporta, 1884 in the Pliocene Tirabuzón Formation near Santa Rosalía, BCS. Mexico. Bull. Southern Ca. Acad. Sci., 84(2): pp. 57-66. 